\title{
El espejismo laico del Ecuador. Los debates constituyentes sobre el aborto, la adopción homosexual y el nombre de Dios en el preámbulo de la Constitución*
}

\author{
Marjorie Gabriela Espinoza Plúa**
}

\section{RESUMEN}

La Constitución ecuatoriana describe el Estado como un Estado Laico. Sin embargo, durante la Asamblea Constituyente de 2007, tres temas pusieron dicha caracterización en aprietos: el derecho a la vida desde la concepción, el matrimonio homosexual, y la inclusión de Dios en el preámbulo de la Constitución. Este texto reconstruye la narrativa de esos debates y demuestra cómo la religión moldeó la conversación e impactó en los textos finalmente aprobados. A la luz de esta descripción se observará que la laicidad estatal en el Ecuador funciona más como un espejismo que como un catalizador para construir una democracia liberal.

PalABras Clave: Asamblea constituyente, estado laico, aborto, matrimonio homosexual, Dios, moral religiosa.

\section{ABSTRACT}

The Ecuadorian Constitution characterizes the State as a Lay State. However, during the Constituent Assembly of 2007 three topics challenged the idea of consecrating Ecuador as a Lay State: the right to life from conception, homosexual marriage and the inclusion of God in the preamble of the Constitution. This paper reconstructs the narrative of those debates and shows how religion shaped the conversation and impacted the provisions that were finally adopted. In light of this description, it is possible to observe that state secularism in Ecuador functions more as a mirage than as a catalyst to build a liberal democracy.

KeYwORDs: Constituent Assembly, secular state, abortion, gay marriage, God, religious morality.

* Una versión extendida de este texto fue publicada en la revista Precedente, vol. 4 (Cali: Universidad ICECI, 2014), bajo el título "La Constitución de Montecristi y sus legados religiosos". Agradezco a la revista Precedente por permitir la difusión de esta versión abreviada.

** Candidata a doctora, Universidad de los Andes, Bogotá. Investigadora asociada de la Universidad de Yale. Maestría en Derecho, Universidad de Yale (L1.M'16). 
L as normas constitucionales que adoptó la Asamblea Constituyente ecuatoriana del año 2008 protegen la vida desde la concepción, prohíben el matrimonio homosexual e incluyen el nombre de Dios en el preámbulo. Reconstruir los debates y narrar la historia de su discusión y aprobación permitirá determinar que su incorporación al texto constitucional buscó satisfacer pretensiones religiosas.

Así, el objetivo de este texto es demostrar las tensiones que consagra la Constitución de Montecristi y que se oponen a la idea de laicidad estatal. ${ }^{1}$ En este sentido, este documento no busca formular una teoría jurídica que explique dichas tensiones, no se trata de un texto normativo. Su objetivo es más limitado, más simple: describir, desde una perspectiva histórica, los debates al interior de la Asamblea Constituyente, entender quiénes fueron sus mayores proponentes, y explicar el impacto que tuvo la religión en los derechos sexuales y reproductivos de las mujeres, así como en los derechos de las personas sexualmente diversas. Sin embargo, para entender las posiciones religiosas y liberales, analizaré brevemente el trasfondo teórico sobre laicisimo.

Enseguida, para ilustrar estas contradicciones y cuestionar el carácter laico del Estado, describiré el contexto en el que nació la idea de una Constituyente, así como el escenario sobre el que se desenvolvió la aprobación de los textos constitucionales. Después, desarrollaré en tres partes las razones que sostienen la crítica al alcance del Estado laico. Por un lado, el manejo político que se dio a estos temas tan pronto como se instaló la Asamblea Constituyente permitirá observar la temprana adopción de decisiones a favor de las demandas religiosas. Por otro lado, la reconstrucción de los debates en el seno de la Asamblea Constituyente relativos a los temas de derecho a la vida desde la concepción, matrimonio homosexual y la inclusión de Dios en el preámbulo de la Constitución dejará ver cómo su discusión se apoyó en argumentos de carácter estrictamente religiosos. Posteriormente, un análisis de la posición religiosa del entonces presidente del Ecuador, quien, durante la Asamblea Constituyente y posteriormente durante la elaboración del Código Penal, manifestó públicamente sus propias convicciones religiosas como razones para no despenalizar el aborto y permitir el matrimonio homosexual, develará cómo ese mismo sesgo se adoptó finalmente en la Constitución. Por último se plantearán unas breves conclusiones.

Con el fin de analizar cómo el debate y la aprobación de los artículos relativos a los temas polémicos señalados supra contradicen la caracterización del Estado como uno

1. El tema de la "laicidad" será explorado desde la idea básica del Estado laico como separado de cualquier tipo de pretensión confesional y por tanto no será abordado desde su análisis teórico. Para un análisis en profundidad de esta naturaleza, ver Jürgen Habermas, “Qué significa una sociedad postsecular?”, en ¡Ay Europa! (Madrid: Trota, 2009); Martha Nussbaum, Las mujeres y el desarrollo humano (Barcelona: Herder, 2012). 
laico me he apoyado en las siguientes fuentes primarias: 1. las actas de las plenarias de la Asamblea Constituyente que transcriben las discusiones, las propuestas y las posiciones de cada asambleísta; 2. las actas de las mesas constituyentes encargadas de redactar los artículos para la aprobación en el Pleno de la Asamblea y que dejan ver cómo se van cambiando los artículos propuestos; 3. las propuestas de normas constitucionales, en torno a los temas señalados, por parte de grupos católicos y evangélicos, y que fueron conocidos por las mesas constituyentes encargadas de elaborar los artículos sobre estos temas; 4. noticias de la prensa escrita que recogen, en este contexto, los debates y posiciones que se generaron durante la Constituyente. Para este efecto, se buscaron las noticias cubiertas y generadas por los periódicos de mayor circulación nacional: El Comercio y El Universo.

El análisis de los documentos señalados, así como las noticias de prensa, siguieron una metodología de investigación histórica crítica. ${ }^{2}$ En esa medida, se busca revelar las tensiones que se generaron en la Asamblea Constituyente y en la sociedad civil de cara a constituir un Estado laico y reconocer a su vez demandas de carácter religiosas. De este modo, las fuentes primarias utilizadas, tanto las directas -las actas de la Asamblea constituyente-, como las indirectas -las noticias de prensa- darán cuenta de los argumentos que sirvieron de base para prohibir el aborto, el matrimonio homosexual e incluir en el preámbulo de la Constitución el nombre de Dios. La aproximación a estas fuentes ha sido contextualizada con los diálogos sociales que se produjeron alrededor de los temas señalados y de los que da cuenta la prensa y los colectivos que llevaron sus demandas hasta Montecristi. Pero también se han contextualizado dentro del marco amplio de transformación política del país que se intentó implementar desde la Revolución Liberal de 1897.

Por último, es importante anotar que el tema de la "laicidad" será analizado desde el punto de vista de los asambleístas constituyentes que demandaban el respeto a este

2. Se adoptará un método crítico en el sentido expuesto por Marc Bloch. Ver Marc Bloch, "La crítica", en Apología para la historia o el oficio de historiador (México: Fondo de Cultura Económica, 2001). Por ello, asumiendo que las fuentes "hablan" solo cuando se les sabe interrogar, este texto se teje alrededor de las siguientes preguntas: ¿Qué tensiones revelan las discusiones en el Pleno y en las noticias de prensa? ¿Quiénes son los actores que participan de este debate? ¿Quién tuvo mayor influencia en la formulación final de los artículos? ¿Qué ideologías soportaron los argumentos esbozados por los asambleístas? ¿Por qué, finalmente, se llegó a las soluciones adoptadas? Del mismo modo, entendiendo la labor reconstructiva del historiador de acuerdo con Edward Carr, intentaré dar cuenta de los debates más relevantes sobre el aborto, Dios y el matrimonio homosexual, el papel que la prensa jugó a la hora de posicionar estos temas, la influencia y el interés político del presidente Correa, así como las posiciones más radicales de la Iglesia católica en estos aspectos. Ver Edward H. Carr, ¿Qué es la historia? (Barcelona: Ariel, 1984). En últimas, la metodología adoptada, siguiendo a Antoine Prost, consistirá, por tanto, en problematizar esos debates así como las soluciones adoptadas. Ver Antoine Prost, "Las técnicas de la crítica, en Doce lecciones sobre la historia (Madrid: Cátedra, 2001). 
paradigma. Por tanto, y considerando que la presente investigación busca privilegiar el matiz histórico de los debates alrededor de las tensiones por la búsqueda de consagrar un Estado laico, serán las mismas concepciones de laicidad de los asambleístas las que sirvan de hilo argumentativo para ilustrar ese concepto. Las posturas que se dieron a favor de la inclusión de este concepto y de su defensa, como se verá, son abordadas desde la idea básica del Estado laico como separado de cualquier tipo de pretensión confesional.

A pesar de que este ensayo no pretende explorar el punto de vista teórico sobre el Estado laico, ${ }^{3}$ es menester situar el lugar donde teóricamente se ubican las posturas que se describirán a lo largo de este trabajo. Por ello, a continuación se realiza una breve reconstrucción de los debates teóricos sobre laicismo como fundamento de los estados constitucionales, y se identifica la postura teórica que sostuvo la discusión en el seno de la Asamblea Constituyente.

\section{EL LAICISMO CLÁSICO COMO TRASFONDO DE LAS POSICIONES SECULARES DE LOS ASAMBLEÍSTAS CONSTITUYENTES}

Todo poder político, aún a partir de la total positivización del Derecho, admite justificaciones normativas; justificaciones que además son siempre ideológicas. En esta medida, este ensayo parte desde la idea de que incluso una justificación secular del poder es también ideológica, como ideológico resulta la inclusión de un punto de vista religioso en la construcción del Estado.

En este marco, y asumiendo la demanda de la laicización de los estados occidentales como parte de los elementos centrales del arquetipo de Estado de Derecho diseñado en Europa a finales del siglo XVIII, resulta, sin embargo, "indiscutible que los ordenamientos liberales dependen de la solidaridad de sus ciudadanos, cuyas fuentes podrían agotarse por completo si se produjera una secularización desencaminada de la sociedad". ${ }^{4}$ Esto sin embargo no supone que, en el contexto de una sociedad pluralista, los principios religiosos adquieran algún tipo de preponderancia, pero sí supone que los valores religiosos forman parte innegable de culturas políticas que dan a luz sus propias constituciones.

3. Para un análisis teórico del laicismo ver Martha Nussbaum, Las mujeres y el desarrollo humano.

4. Jürgen Habermas, Una tarde de discusión entre Habermas y Ratzinger (s. 1.: Academia Católica de Baviera, 2004), 1. 
En efecto, si se atiende a una construcción cultural de la Constitución, entonces se podría decir que una Constitución responde a una "suma de actitudes y de ideas, de experiencias subjetivas, escala de valores y expectativas subjetivas y de las correspondientes acciones objetivas tanto al nivel personal como del ciudadano...", 5 en donde la religión de un pueblo es parte de esa escala de valores, de la percepción del mundo e inclusive de una parte del trasfondo de la vida. Si así se encuadra el problema, ¿entonces desde qué punto de vista se demanda la no injerencia de la religión en el diseño constitucional y en el actuar estatal? ¿Qué se entiende por laicismo? En las sociedades postseculares, ¿cuáles son las premisas normativas que debe imponer el Estado liberal a sus ciudadanos religiosos y no creyentes?

La tradición del derecho racional construye una justificación no religiosa y postmetafísica de los fundamentos normativos del Estado constitucional. Para ello, en el camino de la positivización del Derecho, renuncia a las doctrinas clásicas y religiosas que aportaba el derecho natural. ${ }^{6}$ Sin esa justificación sacra, en un primer momento, se confunden los argumentos morales y religiosos como pretensiones de validez (legitimidad) de un Estado. Desde aquí se podría pensar que la fundamentación del derecho y el poder requieren de una justificación ideológicamente neutral en tanto lo moral se asocia con lo religioso. No obstante, en este ensayo, como se verá más adelante, se adscribe un punto de vista desde el cual puede existir una fundamentación moral del derecho que sea autónoma del punto de vista católico (o religioso en general) en tanto se distingue una moral crítica de una moral religiosa.

En todo caso, el debate sobre la laicidad del Estado adquiere relevancia en tanto que, aceptando una justificación normativa del Estado y el derecho, se entiende, al mismo tiempo, que una sociedad plural implica una diversidad de valores y percepciones del mundo dentro de una misma sociedad, que, sin embargo, en el caso ecuatoriano es mayormente católica. La tendencia laicista, considerada como un paradigma de las sociedades modernas, entraña la separación de los dogmas religiosos en la fundamentación del Estado y de las normas jurídicas que rigen la conducta de los individuos en una sociedad. ${ }^{7}$ Desde aquí, el laicismo puede entenderse en dos vertientes. Por un lado, la vertiente que denominaré 'laica clásica' según la cual las manifestaciones religiosas pertenecen al fuero personal, a la conciencia individual y por tanto no pueden constituir las causas o el fundamento del accionar público del ciudadano y, menos aún, del Estado; y, por otro lado, la vertiente que llamaré 'laica-tolerante', di-

5. Peter Haberle, Teoría de la Constitución como ciencia de la cultura (Madrid: Tecnos, 2000), 37.

6. Para una reconstrucción detallada de la profanación del Derecho y de los elementos legitimatorios del poder estatal ver Jürgen Habermas, Facticidad y validez. Sobre el derecho y el Estado democrático de derecho en términos de teoría del discurso (Madrid: Trota, 2010), capítulos I y III.

7. Para un debate a profundidad ver Habermas, ¿Qué significa una sociedad postsecular? 
señada en Estados Unidos, según la cual existe una tolerancia de las manifestaciones públicas de las creencias religiosas. ${ }^{8}$

En la presente investigación, y de conformidad con las opiniones de los asambleístas constituyentes ecuatorianos que bregaban por la separación de las concepciones religiosas en el diseño de la Constitución y del quehacer estatal, las discusiones sobres los temas que aquí se investigan -el aborto, matrimonio homosexual, e inclusión de Dios en la Constitución- se inscriben en la concepción 'laica clásica' en virtud de la cual se demanda un principio inflexible de neutralidad respecto de las creencias religiosas en la fundamentación de todo el ordenamiento jurídico y en la construcción y dinámicas de la esfera pública. En esta se excluye, por tanto, cualquier 'particularismo' y se atiende a convicciones que tengan una aspiración generalizable, es decir, que tengan posibilidad de ser argumentadas de forma racional y por tanto que puedan ser aceptables y comprensibles universalmente.

En este esquema tradicional de interpretación del laicismo se inscriben los debates que a continuación se presentan. Implícito en ellos está la idea liberal de la privatización de la creencia religiosa y la división tajante de la esfera pública y privada. Esta tendencia laicista, o, como Habermas la denomina, "fundamentalismo de la Ilustración", sostiene pues que "la religión [...] tiene que retirarse del ámbito público de la política al espacio privado porque, desde un punto de vista cognitivo, es una "figura del espíritu' históricamente superada...". 9

Con este enfoque laicista se describirán los debates sobre los tres temas indicados, al tiempo que se privilegiará el punto de vista de los asambleístas sobre sus propias concepciones de laicismo y de la neutralidad estatal. De ellos se desprende un concepto muy cercano al que teóricamente se ha expuesto. ${ }^{10}$ Estas posiciones liberales clásicas tienen, sin embargo, como punto de contrapartida las posiciones conservadores de los asambleístas que bregaban por la inclusión de sus intereses en la Constitución a partir de justificaciones netamente religiosas. Si a las razones religiosas se les oponía la total laicidad, a la laicidad se le oponía directamente la palabra de Dios plasmada en la biblia. Veamos.

8. Para un análisis de esta postura, ver Alexis de Toqueville, La democracia en América (Madrid: Trotta, 2010); y Ronald Dworkin, Religion without God (Cambridge/London: Harvard University Press, 2013).

9. Ibíd., 77.

10. El punto de vista laico y laicista, que algunas autores han expuesto como distintos, en tanto el primero supone un reconocimiento al papel positivo que las creencias pueden jugar en la esfera pública, y el segundo, una visión extrema secularista, son en esta investigación tratados de forma indistinta. 


\section{LA PUESTA EN ESCENA Y LOS PERSONAJES PRINCIPALES}

\section{Macrocontexto: las ideas de Eloy Alfaro Y LA REVOLUCión LiBERAL}

La Revolución Liberal en el Ecuador se dio en 1895 y fue liderada por el general Eloy Alfaro, oriundo de la provincia de Manabí, cantón Montecristi, lugar en donde ciento cincuenta (150) años más tarde se instaló la Asamblea Constituyente, que dio origen a la Constitución vigente.

A través de una agenda liberal, Alfaro llevó a cabo una revolución radical que pretendía transformar al país. Para ello emprendió una reforma política y social que, entre otras, incluyó la separación radical de la iglesia y el Estado. Con este propósito no solo buscó alejar de los asuntos públicos cualquier tendencia confesional sino que incluso emprendió campañas anticlericales: expulsó a los miembros de la Compañía de Jesús y a todo fraile extranjero que hubiera participado en los intentos de derrocar a su Gobierno, nacionalizó las propiedades del clero, suprimió varios conventos y monasterios, impuso la enseñanza laica y obligatoria, y expropió las propiedades agrícolas de la Iglesia que se encontraban abandonadas o que no habían sido suficientemente trabajadas. ${ }^{11}$ Tal era su posición del papel del Estado y de la Iglesia: la autoridad civil y la eclesiástica deben ser independientes, la Iglesia debe reducir su rol en el control de la moralidad y de la educación. Para permitir la implantación de estos profundos cambios también promocionó el diseño y la promulgación de la Constitución de 1906 en la que concretó sus principios liberales. De modo que, en vez de consagrar una religión o iglesia oficial, no solo no hizo alusión alguna a Dios, sino que además estableció que la enseñanza pública fuera esencialmente seglar y laica. ${ }^{12}$ Vale la pena señalar que hasta entonces las constituciones mantenían la misma base de redacción y estructura en la cuestión religiosa.

La Constitución de 1897, precedente a la de 1906, señalaba: “Art. 12. La Religión de la República es la católica, apostólica, romana, con exclusión de todo culto contrario a la moral. Los Poderes públicos están obligados a protegerla y hacerla respetar”.

11. Tales acciones correspondían al programa ideológico que Alfaro esbozó en su "Decálogo Liberal” y que lo publicó en el periódico El Pichincha, de 1895. Ver Ángel Emilio Hidalgo, "Una interpretación de la Hoguera Bárbara: Quito, 28 de enero de 1912”, Procesos: Revista ecuatoriana de historia, Quito (2012).

12. “Artículo 16. La enseñanza es libre, sin más restricciones que las señaladas en las leyes respectivas; pero la enseñanza oficial y la costeada por las Municipalidades, son esencialmente seglares y laicas". Constitución del Ecuador. Promulgado el 23 de diciembre de 1906. 


\section{Contexto histórico Reciente: Rafael Correa y la Constituyente de Montecristi detrás de la huella de Alfaro}

Muchos años más tarde, entra en la escena política del Ecuador Rafael Correa. Apoderado de un discurso revolucionario que pretendía transformar las bases sociales, políticas y económicas de un país que atravesaba una grave crisis institucional, gana las elecciones presidenciales en el año 2007.

Correa nació en Guayaquil, en el seno de una familia de clase media. Mientras estudiaba en la Universidad Católica de Guayaquil, se involucró en el quehacer de grupos cristianos, puntualmente con los salesianos, con quienes trabajó un año como misionero en una de las parroquias más pobres de los páramos de la Sierra Central de Ecuador, donde aprendió kichwa. ${ }^{13}$ Su discurso se caracterizó por la evocación frecuentemente a las ideas de Eloy Alfaro y a su revolución radical, ideas que se han convertido en referente y fundamento de la puesta en práctica del programa de gobierno denominado "Revolución Ciudadana". Las constantes alusiones a las ideas revolucionarias de Alfaro se constituyeron como fundamentos para legitimar los procesos revolucionarios de la agenda de Correa, de modo que su primer acto de gobierno fue llamar a una consulta ciudadana para decidir sobre la realización de una Asamblea Constituyente con el fin de elaborar una nueva Constitución. ${ }^{14}$

Así, el 30 de noviembre de 2007 se instaló la Asamblea Constituyente en la ciudad de Montecristi. Para ese efecto se construyó un centro de convenciones llamado precisamente Ciudad Alfaro. En la inauguración de Ciudad Alfaro y en el inicio de las actividades constituyentes, evocando la inspiración de Eloy Alfaro, Correa señaló enfáticamente: "tenemos la certeza que el camino emprendido por la Revolución Ciudadana es un camino de vindicación de la huella del general Alfaro". ${ }^{15}$

Tras ocho meses de trabajo en la Asamblea, y con el proyecto de Constitución finalizado, Correa volvió a invocar el nombre de Alfaro: "Esta Constitución, a diferencia de la del 98, ha sido trabajada bajo el amparo, la inspiración, la espada del espíritu

13. Rickard Lalander y Pablo Ospina Peralta, "Movimiento indígena y revolución ciudadana en Ecuador", Cuestiones Políticas, vol. 28, No. 48 (2012): 13-50.

14. La pregunta fue en este tenor: ¿Aprueba usted que se convoque e instale una Asamblea Constituyente con plenos poderes, de conformidad con el Estatuto Electoral que se adjunta, para que transforme el marco institucional del Estado, y elabore una nueva Constitución?

15. Presidencia de la República. Discurso del presidente Rafael Correa en la recepción de los restos del general Eloy Alfaro a Montecristi. Montecristi, 30 de noviembre de 2007. 
libertario de Eloy Alfaro Delgado". ${ }^{16}$ El 20 de octubre de 2008, mediante referéndum, Ecuador aprobó su nueva Constitución, la Constitución de "Montecristi".

\section{La Asamblea Constituyente, PERSONAJES Y DEBATES ESENCIALES}

La Asamblea Constituyente estuvo integrada por ciento treinta (130) asambleístas de los cuales ochenta (80) eran del partido de gobierno denominado, en ese entonces, Acuerdo País (AP). Además, por primera vez en la historia, la Asamblea se integró por un $36,41 \%$ de mujeres, algo jamás visto en Ecuador.

Acuerdo País, bloque de mayoría, estaba integrado a su vez por varios movimientos políticos que compartían objetivos comunes con la agenda de la Revolución Ciudadana. Sin embargo, pronto se comenzaron a develar tensiones ideológicas al interior del bloque; cuestión que se hizo evidente a la hora de tratar los temas objeto de esta investigación: el aborto, el matrimonio homosexual, y la inclusión de Dios en el preámbulo de la Constitución. La discusión sobre esos temas adquirió una relevancia y notoriedad nunca antes vista en el país. ${ }^{17}$ De hecho, el aborto fue el tema de mayor cobertura mediática.

De un estudio realizado sobre los temas que más cubrió la prensa se obtuvo que:

de 597 formatos periodísticos; el 44\%, con 260 formatos exclusivamente fueron de aborto, mientras que, 337 informaciones, equivalentes al 56\%, cubrieron las otras 6 categorías de análisis: Tipos de familias, (unión de hecho entre personas del mismo sexo); Estado laico (Dios en la Constitución); Salud y derechos de las mujeres (género, placer sexual, derechos reproductivos y sexuales, educación sexual). ${ }^{18}$

En este escenario, nació una división irreconciliable en el seno de Acuerdo País. Por un lado, asambleístas feministas y defensoras de los derechos de las mujeres: María Paula Romo, Betty Amores, Rosana Alvarado, Tania Hermida, María Soledad Vela, Gina Godoy y María Augusta Calle. Por el otro lado, el entonces presidente de la República, Rafael Correa, y los asambleístas Rolando Panchana, Rosana Queirolo y Diana Acosta. Estas dos últimas asambleístas terminaron por abandonar el bloque

16. Presidencia de la República del Ecuador. Intervención del presidente de la República, Rafael Correa en la ceremonia de clausura de la Asamblea Nacional Constituyente. Montecristi, 25 de julio de 2008.

17. Ver Paula Castello Starkoff, "Despenalización del aborto y nuevo proyecto constitucional: un tema polémico", Íconos: Revista de Ciencias Sociales, Quito (2008): 22.

18. Elizabeth Herrera y Paulina Ponce, Mujeres a media tinta ¿Cómo trató la prensa escrita ecuatoriana los derechos de las mujeres durante la Asamblea Constituyente? (Quito: CONAMU, 2008), 44. 
oficialista y se alinearon con las facciones conservadoras de la Asamblea Constituyente representadas por el Partido Renovador Institucional Acción Nacional (PRIAN), el Partido Sociedad Patriótica (PSP) y el Partido Social Cristiano (PSC). Desde aquí nació un grupo de mujeres asambleístas que, acompañadas por la Iglesia católica y evangélicas, se abanderaron de la posición "pro vida" y defendieron el derecho a la vida desde la concepción -sin excepciones-, la prohibición del matrimonio o unión homosexual, y la evocación a Dios en la Constitución. Estas mujeres eran: Anabel Azin y Gissel Rosado (PRIAN); Cristina Reyes y María Cristina Kronfle (PSC). También fueron apoyadas por asambleístas evangélicos y conservadores: César Rohón, Andrés Pavón, Julio Logroño, Valerio Estacio y César Grefa.

Cada posición así enfrentada contaba con el soporte y movilización de organizaciones de la sociedad civil. En este sentido, podríamos ilustrar el escenario así enfrentado entre una posición a la que se llamará "progresista" y otra "conservadora". La primera estaba conformada por las asambleístas mencionadas, por la coalición política "Movimiento de Mujeres del Ecuador", y por el extinto Consejo Nacional de Mujeres (CONAMU). Conjuntamente, formularon una agenda temática que refrendaba el derecho a la vida en términos generales -explícitamente no abordaba el tema del aborto-; se refería al matrimonio de manera genérica sin mencionar a la unión entre un hombre y una mujer; y consagraba un artículo para la definición de lo que significa un Estado Laico. ${ }^{19}$

En el segundo, se encontraban los grupos conservadores que buscaron que los principios religiosos fueran el modelo de vida y fundamenten los principios del Estado. Junto a las asambleístas indicadas, se unieron a las cúpulas de la Iglesia católica: el presidente de la Conferencia Episcopal Ecuatoriana, Antonio Arregui, seguidor del Opus Dei, y el pastor evangélico Francisco Loor. Estos grupos religiosos también hicieron propuestas de textos constitucionales ${ }^{20} \mathrm{e}$ incluso establecieron una comisión

19. Su propuesta de articulado respecto del Estado laico fue la siguiente: “Art. XX. El Ecuador se proclama como Estado laico. Ninguna religión es o puede ser la del Estado. Se establece la separación entre Estado e Iglesia como esferas autónomas, el Estado no debe auspiciar, proteger, financiar ni favorecer a una religión en particular. Sus decisiones no pueden ser justificadas en determinado dogma creencia religiosa. Tampoco le corresponde desarrollar acciones contra ninguna expresión religiosa". En relación con el matrimonio proponía: Art. XX. La unión estable y monogámica de dos personas libres de vínculo matrimonial con otra persona, que formen un hogar de hecho generará los mismos derechos y obligaciones que tienen las familias constituidas mediante matrimonio o casamiento, inclusive en lo relativo a la presunción legal de paternidad, sociedad conyugal y derecho de sucesión”. Este documento fue entregado en el Pleno de la Asamblea el día 8 de marzo a propósito del día de la mujer. Archivo Asamblea Nacional. Asamblea Constituyente. Actas del Pleno. Acta No. 025. 7 de marzo de 2008.

20. Sus propuestas alrededor de la vida humana y la familia fueron las siguientes: "La vida humana es inviolable desde el momento mismo de su concepción hasta su muerte natural". "De la protección a la familia.- El Estado reconoce y protege a la familia conformada por un hombre y una mujer, corno célula fundamental 
de seguimiento para ayudar consultivamente a las mesas constituyentes en temas relativos a la persona, la vida, la familia, la libertad (religiosa y educativa) y la justicia social. $^{21}$

Queda así enmarcado el debate constitucional, con sus protagonistas y temas de (des)encuentro.

\section{MANEJO POLÍTICO DE LA RELIGIÓN}

El derecho a la vida desde la concepción, el matrimonio homosexual y la inclusión de Dios en la Constitución fueron objeto de debate desde el inicio de la Asamblea Constituyente. Cuando el tema se comenzó a posicionar en la agenda de los grupos pro-vida y los asambleístas afines a estas ideas, Acuerdo País intentó evadir los temas por considerarlos como "no constitucionales", pretendiendo que la discusión no ocasionara un debate que podría ser contraproducente para aprobar la Constitución.

Algunas agrupaciones de mujeres advertían, sin embargo, que "la Asamblea no puede dejar a un lado este debate por miedo a que haya una campaña por el no en el referéndum aprobatorio". ${ }^{22}$ En esto coincidían tanto los grupos pro derechos de las mujeres, y los grupos pro-vida y las cúpulas religiosas quienes organizaron varias marchas para que estos temas fueran tratados en la Constitución. ${ }^{23}$

El momento decisivo que obligó a la Asamblea a dar una respuesta a estas pretensiones fue la participación de las asambleístas oficialistas Rosana Queirolo y Diana Acosta en la marcha realizada en homenaje al Día del Niño por Nacer. También apoyaron y participaron de esta marcha otras asambleístas de oposición: Cristina Reyes, Anabella Azín, Giselle Rosado. Esta fue una de las varias marchas y acciones que se llevaron a cabo, y que, hasta el final de la Asamblea Constituyente, les permitió recoger ochocientas mil (800.000) firmas para que no se permita la despenalización del aborto, ni el matrimonio entre personas del mismo sexo, y para que conste el nombre de Dios en la Constitución. ${ }^{24}$

de la sociedad [...]. Archivo de la Asamblea Nacional. Asamblea Constituyente. Propuesta de la Conferencia Episcopal Ecuatoriana. Mesa 3. Caja 5. Folder 58. Dispositivo 5. 14 de abril de 2008.

21. "El Gobierno no quiere correr riesgos en el referéndum", El Comercio, Redacción Política, 6 de abril de 2008.

22. "La Asamblea Constituyente sí debatirá temas polémicos", El Comercio, 27 de abril de 2008.

23. "Propuesta: los cristianos en contra del aborto", El Comercio, 26 de marzo de 2008.

24. Ibíd. 
Este hecho fue el inicio del fin de la adhesión de Queirolo y Acosta al partido de Acuerdo País, lo que reveló tensiones al interior del bloque y obligó al partido oficialista a pronunciarse sobre estos temas.

\section{El Comunicado religioso de Acuerdo País}

Las marchas emprendidas por los asambleístas señaladas despertaron el rechazo de varios miembros de su agrupación, pero también lograron el apoyo del entonces presidente de la República, quien había señalado que si la Constitución permitía el aborto él mismo votaría NO. ${ }^{25}$ En medio de estas tensiones, Correa convocó a su bloque a una reunión en Montecristi para determinar la manera de encauzar estos temas polémicos de tal forma que no fueran motivo de una campaña para votar NO en el referendo aprobatorio. De la reunión que Correa mantuvo con sus asambleístas se publicó un comunicado a la ciudadanía que señalaba:

\section{COMUNICADO ACUERDO PAIS:}

El bloque de Acuerdo País aclara a la ciudadanía:

1. El respeto absoluto e irrestricto a todas las convicciones y creencias del pueblo ecuatoriano.

2. El carácter laico del Estado como garantía de libertad e independencia de la organización de la sociedad frente a las convicciones religiosas.

3. El preámbulo de la Constitución incorporará de manera ecuménica el nombre de Dios y las diversas formas de religiosidad, espiritualidad y creencias de los ecuatorianos.

4. La nueva Constitución garantizará la vida. Y la reconocerá y protegerá en todas sus etapas, incluidos el cuidado y la protección desde la concepción.

5. El matrimonio se mantendrá como la unión de un hombre y una mujer. ${ }^{26}$

Como se ve, aunque el comunicado reconocía que se respetarían las convicciones y creencias del pueblo ecuatoriano, el Bloque de Acuerdo País aceptaba, sin embargo, la incorporación del nombre de Dios en la Constitución, la garantía de la vida desde la concepción y el matrimonio entre hombre y mujer, prohibiendo que esta institución se extienda a parejas del mismo sexo. El comunicado reveló entonces una tensión importante: el deseo de reconocer derechos en el marco de un Estado laico, pero también un límite a dicho reconocimiento: las creencias religiosas.

25. "Dios, aborto y matrimonio homosexual no deben ir en la Constitución, según Cordero", El Comercio, 26 de marzo de 2008.

26. “Asamblea aprueba cinco primeros artículos de la nueva Constitución”, El Comercio, 1 de abril de 2008. 
A pesar de que el comunicado daba razón a las asambleístas Queirolo y Acosta, y por tanto a las pretensiones de las iglesias en cuestión, dichas asambleístas se desafiliaron de Acuerdo País pues no se aseguraba la vida desde la protección sin excepciones, y porque no se prohibía expresamente la unión libre entre homosexuales.

El comunicado suscitó una serie de cuestionamientos. En lo relativo al aborto, el Movimiento Nacional de Mujeres, así como grupos GLBT, denunciaron este acuerdo al abrir la posibilidad de desconocer el aborto terapéutico, ${ }^{27}$ y por evidenciar "el poder de las religiones en el Ecuador". ${ }^{28}$ Los columnistas de prensa también rechazaron el acuerdo y tildaron a Correa de conservador y retardatario:

El gobierno del presidente Correa pasará a la historia como uno de los más conservadores y retardatarios del período democrático que se inició en 1979 [...] Esta semana, el bloque oficialista de la Asamblea decidió, sin mayor debate, incluir el nombre de Dios en la Constitución, prohibir el matrimonio homosexual y el derecho al aborto. [...]La inclusión de Dios en la Constitución es un error que pudiera romper uno de los puntales sobre los cuales se ha construido la democracia liberal: el secularismo. ¿Conclusión? El Gobierno no quiere cambiar este país. Solo quiere ganar las elecciones y mantenerse en el poder. ${ }^{29}$

El debate se volvió a encender a la hora de debatir y aprobar los artículos relativos a esos temas. Recuérdese que, hasta ese momento, todo fue un manejo político pues la discusión aún no se había trasladado al Pleno de la Asamblea Constituyente, de manera que, cuando los asambleístas comenzaron a debatir los artículos relativos al derecho a la vida y los derechos sexuales y reproductivos, la discusión se reavivó y las asambleístas que apoyaban los derechos de las mujeres buscaron maneras de evitar que la 'promesa' de la garantía de protección a la vida desde la concepción signifique un impedimento para acceder al aborto terapéutico. Estos debates serán tratados en el apartado cuarto de este trabajo.

\section{LA CARTA INFILTRADA: SESGO RELIGIOSO Y CÁLCULOS ELECTORALES}

La confrontación entre el bloque mayoritario y los asambleístas conservadores de oposición se hizo más fuerte cuando en el marco de la discusión de los artículos sobre derechos civiles, que incluían el derecho a la vida y los derechos sexuales y reproductivos, se filtró una carta que el secretario particular del presidente Correa envió

27. "Las organizaciones de mujeres rechazaron posición de A. País", El Comercio, 2 de abril de 2008.

28. Ibíd.

29. Gonzalo Maldonado Albán, "Conservador y retardatario". El Comercio, 6 de abril de 2004. 
al coordinador de Acuerdo País, Galo Borja, con copia al entonces presidente de la Asamblea Constituye, Fernando Cordero, en la que se revela el temor por el rechazo de la Iglesia Católica al proyecto constitucional. La carta fue leída en el Pleno de la Asamblea por Pablo Lucio Paredes y también fue publicado en la prensa:

Estimado Galo: como recordarás, aquel desagradable e indignante día en que se fueron del bloque la Queirolo y la Acosta, resolvimos tres cosas, que inclusive constaron por escrito: 1. Que se garantice el derecho a la vida desde la concepción (recuerda que la pelea con las ahora desleales opositoras es que querían que se incluya "sin excepciones", lo cual no aceptamos). 2. Que se incluya el nombre de Dios en la Constitución. 3. Que se deje el tema de los derechos de los gays para normas secundarias, y no elevarlo a norma constitucional. En lo que respecta al primer punto, que es fundamental para que no tengamos el rechazo oficial de la Iglesia, la Mesa 1 cambió la redacción -contrariando lo que habíamos acordado-y puso, con respecto a los derechos de los niños, lo siguiente: "El Estado les asegurará la protección y cuidado desde la concepción". Cuando lo que habíamos convenido era: "El Estado garantizará la vida desde la concepción". Por lo que el Presidente se siente una vez engañado cuando lo que convenimos no se cumple. [...] Este tema es FUNDAMENTAL para que no tengamos a la Iglesia pidiendo el No en el referéndum, como ya lo insinuó en todos los púlpitos del país el domingo pasado y que sería políticamente desastroso [...] Alexis Mera Giler [las cursivas me pertenecen]. ${ }^{30}$

El mismo asambleísta finalmente señaló: "en esta carta no se dice que se quiere defender el principio ese porque se cree en el principio, sino que el tema es para que la Iglesia católica no se enoje y para que eso no afecte el referéndum". ${ }^{31}$ La carta demostraba que los temas eran relevantes por razones electorales y evidenció la enorme influencia de la iglesia católica en la política ecuatoriana, contradiciendo el carácter laico del Estado.

\section{DEBATES CONSTITUYENTES: LEVANTANDO EL VELO DE LOS ARGUMENTOS CONSERVADORES}

Alrededor de los temas planteados se originaron posiciones enfrentadas, circunstancia que se dio tanto en el seno del bloque mayoritario de la Asamblea Constituyente, y con este y grupos de oposición que eran minoritarios y conservadores. Estos últimos, apoyados por la iglesia católica y evangélica, buscaron que se incluyera, con precisión, el derecho a la vida desde la concepción de modo que no se permitiera bajo

30. "Mujeres denuncian injerencia de asesor de Correa en Asamblea", El Universo, 5 de julio de 2008.

31. Actas del Pleno, Acta No. 77, 155. 
ninguna circunstancia el aborto; el matrimonio y la unión libre como institución que cobije solo a parejas de distinto sexo y que se incluya a Dios en la Constitución. La defensa de estos tres asuntos se fundamentó, sobre todo, en argumentos morales religiosos.

En este texto se asume que existen diferencias entre moralidad religiosa, como una ética individual, y moralidad crítica o moralidad racional, con la que es posible argumentar racionalmente en decisiones que atañen a toda la comunidad. La primera tiene que ver con argumentos teológicos cuya base son dogmas de fe que, por lo mismo, no se cuestionan pues no tienen fundamentos que puedan explicarse racionalmente; se asumen acríticamente. La segunda tiene que ver con una posición cognotivista de la moral ${ }^{32}$ que, por tanto, puede ser justificada a través de pretensiones de validez que sean aceptadas libremente por todos los participantes en discursos racionales. ${ }^{33}$

Tal como se observará, solo marginalmente algunos asambleístas aportaron con explicaciones no religiosas puntualmente a la hora de defender la vida desde la concepción. En otras palabras, bien se podría esperar que las discusiones en contra del matrimonio homosexual o en contra del aborto puedan articularse mediante argumentos morales racionales, ${ }^{34}$ sin embargo, ese no fue el caso en los debates en la Asamblea.

Los argumentos de carácter religioso esgrimidos por los asambleístas podrían clasificarse en tres tipos, más el argumento jurídico:

a) El mito de la mayoría católica: este se esbozó como uno de los principales argumentos a la hora no solo de incluir el nombre de Dios sino de prohibir cualquier artículo que habilitara la posibilidad del aborto o del matrimonio o unión homosexual. Este razonamiento indica que la mayor parte de la población ecuatoriana es católica, y por tanto los valores católicos, como la sacralidad de la vida, de la familia, del matrimonio y la centralidad de Dios, deben ser considerados en la Constitución. Un argumento de esta naturaleza supone la imposición de un tipo de moral que se considera mayoritaria: la moral católica. El contraargumento sería el carácter laico del Estado, y por tanto el respeto a la libertad de conciencia y a toda manifestación religiosa y/ o filosófica.

32. Ver I. Kant, Crítica de la razón práctica (Madrid: Espasa-Calpe, 1981). También Ronald Dworkin, Moral Freedom's law: The Moral Reading of the American Constitution (Cambridge: Harvard University Press, 1996).

33. Jürgen Habermas, "Del uso pragmático, ético y moral de la razón práctica", en Aclaraciones a la ética del discurso (Madrid: Trotta, 2000).

34. Ver Richard Posner, Against Constitutional Theory (New York: University Law Review, 1998). Ver también Lawrence $v$. Texas, 539 U.S. 558, 602, 2003 (opinión del Juez Antonin Scalia). 
b) La Biblia como fuente de Derecho: este argumento fue igualmente utilizado en los tres temas señalados, pero sobre todo en lo que concierne a la invocación de Dios en la Constitución y a la prohibición del aborto. A partir de este razonamiento se hacen afirmaciones tales como que solo Dios tiene la potestad sobre la vida, y que como tal la vida es un don divino. Al utilizar estos argumentos los asambleístas leían versículos de la Biblia y en esa medida pretendían dotar de normatividad jurídica los mandatos religiosos de la Biblia.

c) Falacia naturalista: este razonamiento fue muy utilizado a la hora de argumentar en contra del matrimonio o unión libre homosexual, y a favor de la prohibición absoluta del aborto. Para ese efecto, basaban sus argumentos prescriptivos: el matrimonio debe ser solo entre un hombre y una mujer, basándose en razonamientos descriptivos: hombre y mujer pueden procrear. El salto argumentativo de uno (lo normativo) a otro (lo descriptivo) viene acompañado por un "así lo quiso Dios".

d) Argumento jurídico: estos razonamientos, aunque marginales, aludían a derechos consagrados en los instrumentos internacionales y a su supremacía en el derecho interno.

Por su parte, los grupos que no apoyaban la inclusión en el texto constitucional del derecho a la vida desde la concepción, que querían reconocer el matrimonio o la unión libre para cualquier tipo de parejas, y que se negaban a incluir el nombre de Dios en la Constitución, eran asambleístas progresista de izquierda, miembros del bloque mayoritario, ${ }^{35}$ y que para sostener esas posiciones aludían al carácter laico del Estado. Este principio les servía para demostrar que los derechos debían ser concebidos y ejercidos sin la mediación de interpretaciones religiosas. Por eso, en varias ocasiones solicitaron que se explicitara una definición del carácter laico del Estado.

A continuación, se ilustrarán los argumentos con los debates e intervenciones que se dieron en el pleno de la Asamblea y en las mesas constituyentes al abordar estos temas. Para el efecto, el siguiente estudio se realizará de acuerdo a esa división temática.

\section{EL DERECHO A LA VIDA Y LOS DERECHOS SEXUALES Y REPRODUCTIVOS: "EL CAMINO PARA EL ABORTO"}

A propósito de la redacción y aprobación de los derechos civiles, el tema sobre el aborto comenzó a tratarse en el seno del Pleno de la Asamblea Constituyente. Los gru-

35. La posición de ese grupo en torno a estos temas coincidía con otros asambleístas de izquierda no aliados al oficialismo como Martha Roldós y León Roldós. 
pos feministas o progresistas abogaban porque en esta sección se consagre el derecho a la vida como tradicionalmente ha constado en todas las constituciones desde 1896 con la fórmula siguiente: "se reconoce el derecho a la vida. No hay pena de muerte". Por su lado los asambleístas conservadores pedían que el derecho a la vida fuera escrito de esta manera: "Derecho a la vida desde la concepción hasta la muerte natural"; es decir, en términos exactos a los propuestos por la Conferencia Episcopal Ecuatoriana.

El Informe de Mayoría ${ }^{36}$ de la mesa 1 encargada de desarrollar el articulado sobre derechos civiles mantuvo la redacción del derecho a la vida en iguales términos que las constituciones que le antecedieron. También incluyó la garantía a la vida desde la concepción en la sección de los derechos de la niñez y la adolescencia, como la Constitución de 1998. Pero aquí había un cambio: la Constitución de 1998 reconocía expresamente el derecho a la vida desde la concepción; la propuesta de la Mesa 1, en cambio, decía: "El Estado les asegurará y garantizará la protección y cuidado desde la concepción". ${ }^{37}$

Los asambleístas conservadores protestaron pues consideraban que el derecho a la vida así redactado era incompleto y no protegía la vida desde la concepción. Leonardo Viteri, Cristina Reyes y Rosana Queirolo propusieron que el artículo fuera redactado en estos términos: "El derecho a la vida, la vida humana sin excepciones es inviolable desde el momento mismo de su concepción hasta la muerte natural". ${ }^{38}$ Con algunas variaciones en la forma, ese mismo artículo fue apoyado por varios asambleístas. ${ }^{39}$

36. En el que señalaban: "La Mesa No. 1 ha realizado un proceso amplio de reflexión colectivo con la ciudadanía a fin de recopilar los criterios y aspiraciones que deberán estar presentes en la nueva Constitución. Con este propósito, se ha recibido más de 160 vistas de una amplia gama de representantes de varios sectores de la población, quienes han concurrido a presentar propuestas y sugerencias para incluir nuevos derechos o ampliar y ratificar los ya reconocidos en la Constitución de 1998. Además, vía internet, se recibieron más de 120 propuestas en la Mesa. También se realizaron 6 mesas itinerantes que contaron con una amplia convocatoria y que tuvieron la finalidad de promover la participación de la ciudadanía, recopilar propuestas y realizar debates interactivos sobre diversos temas de trascendencia para enriquecer los textos a ser elaborados por las y los asambleístas. Por otra parte, se ha tenido en cuenta los estándares internacionales establecidos en diversos tratados de derechos humanos que han sido ratificados por el Ecuador y que constituyeron puntos de referencia respecto a los contenidos mínimos que debían tener los derechos. [...]”. Archivo Asamblea Nacional. Asamblea Constituyente. Actas del Pleno. Acta No. 050, del 12 de mayo de 2008.

37. Archivo de la Asamblea Nacional. Asamblea Constituyente. Mesa 1. Acta No. 44-08. Caja 2. Folder 17. Dispositivo 8.

38. Ibíd., 64.

39. La Mesa 1 recibió después del segundo debate varias propuestas tales como: "La vida se garantiza y se protege desde la concepción hasta la muerte natural. De Rory Regalado". "La inviolabilidad de la vida en todas sus etapas, desde la concepción hasta la muerte natural. No hay pena de muerte. De Rosa Queirolo". "Inviolabilidad de la vida, desde la concepción hasta la muerte natural. No hay pena de muerte. De Mario 
Las justificaciones para que así fuera se dieron a través de los tipos de argumentos señalados supra.

Así, por ejemplo, Gisel Rosado indicaba que los articulados propuestos por la Mesa 1 atentaban contra sus principios éticos, morales y religiosos, y agregaba el argumento del mito de la mayoría católica: "nos estamos olvidando de lo fundamental. El noventa y nueve por ciento de los que estamos aquí tenemos una creencia, creemos en Dios, y en esta Constitución lo están demostrando". ${ }^{40}$ Diana Acosta aludía, igualmente, al clamor de la "ciudadanía", del pueblo católico de quien se sentía representante:

Soy defensora de los derechos de las mujeres pero eso no quiere decir que una mujer tiene derecho a decidir sobre una vida que no le pertenece. Las mujeres tenemos derecho a cortarnos el pelo, a pintarnos el pelo, hacerse las cirugías que quieran. No aceptamos, yo no admito, muchos colegas aquí no admitimos, la ciudadanía no admite, evangélicos, católicos, cristianos y muchos ciudadanos no admitimos que se diga que se respeta el cuidado y la protección desde la concepción. ${ }^{41}$

César Rohón, haciendo uso del argumento de la Biblia como fuente de Derecho confesaba que, después de investigar sobre el tema de la concepción desde la vida, encontró en ese texto su fundamento:

Me fui a un libro que todos conocemos, pero que muy pocos lo lee, que es, la Sagrada Escritura, la Biblia, y me encontré con un versículo que me parece maravilloso, es el salmo ciento treinta y nueve, el versículo tres, y dice así, 'Porque tu formaste mis entrañas, tu me hiciste en el vientre de mi madre'. Qué maravilloso. Y encontré en las escrituras, la respuesta que andaba buscando hace mucho tiempo, del fundamento principal, para poner en la Carta Fundamental de nuestra Nación, el derecho a la vida desde la concepción. Y aquí está la respuesta. Maravilloso, ese el Dios grande y poderoso que tenemos que nos da la vida, que desde la entrañas de nuestra madre nos vio y nos engendró. Qué maravillo, qué maravilloso, poder compartir eso aquí esta mañana. ${ }^{42}$

Pero también se encontró en la lectura de las actas el intento de las asambleístas conservadoras por alejar el debate de argumentos religiosos; sin embargo, a la hora de fundamentar la importancia de la protección a la vida desde la concepción, sus argumentos les llevaban a invocar a Dios como el dador de la vida; así lo apuntaba la asambleísta Queirolo:

Játiva Reyes”. En Archivo de la Asamblea Nacional. Asamblea Constituyente. Mesa 1. Acta No. 037. Caja 3. Folder 3. Dispositivo 7. 27 de mayo de 2008.

40. Acta del Pleno, Acta No. 050, 77.

41. Ibíd., 22.

42. Ibíd., 56-7. 
Aquí no se tratan de temas religiosos, se trata de hablar científicamente. Los médicos ginecólogos de la FLACSO, ya lo determinaron, este es un tema científicamente comprobado. Sí, aunque no lo quieran aceptar, la vida existe desde el momento mismo de la concepción, cuando Dios decidió que nosotros vengamos al mundo. ${ }^{43}$

En contraposición, Rosana Alvarado pedía que el tratamiento de estos temas se desprendiera de conceptos religiosos y proponía la defensa de la vida de las mujeres:

La vida de las mujeres entonces no puede estar supeditada a la concepción dogmática y religiosa que propone la defensa de una vida que podría significar la muerte de las mujeres [...] Nos defendemos desde la convicción que significa reconocer que el Estado ha vivido sin reconocer los derechos de las mujeres, ha vivido violentando sistemáticamente los derechos de las mujeres bajo el paraguas del dogma religioso, bajo el paraguas de que la religión puede y está por encima de la decisión, de la decisión bien fundamentada integrada y ética que sí tenemos las mujeres. ${ }^{44}$

El aborto y la protección a la vida desde la concepción fue nuevamente motivo de debate al momento de discutir el articulado sobre derechos sexuales y reproductivos. El Informe de Mayoría de la Mesa 1 buscó separar y explicitar dichos derechos con el fin de romper el paradigma del ejercicio sexualidad femenina (derechos sexuales) ligada a la maternidad (derechos reproductivos). ${ }^{45} \mathrm{El}$ articulado propuesto reconocía esos derechos en este tenor:

Derechos sexuales: toda persona tiene derecho a tomar decisiones libres e informadas y responsables sobre su sexualidad y vida sexual, incluida la identidad sexual, de género y la orientación sexual. El Estado sancionará todo acto de violencia sexual, prostitución forzada y esclavitud sexual o cualquier otra forma o expresión que atente contra los derechos sexuales.

Derechos reproductivos: toda persona tiene derecho a tomar decisiones libres, responsables e informados sobre su salud y vida reproductiva, y a decidir cuándo y cuántos hijos, hijas tener y cada qué tiempo"46 (las cursivas me pertenecen).

María Soledad Vela, participante de la Mesa 1, enfatizó el aporte del articulado propuesto reiterando que la separación de los derechos reproductivos de los sexuales busca desvincular "la reproducción de la sexualidad, liberando a la mujer de su

\footnotetext{
43. Actas del Pleno, Acta 050A, 12.

44. Actas del Pleno, Acta No. 050, 112.

45. Ibíd., 35-6.

46. Ibíd., 37.
} 
imagen, exclusivamente, reproductora [...]". ${ }^{47} \mathrm{Al}$ dotar de autonomía a los derechos reproductivos, se busca que las decisiones sobre reproducción se produzcan sin interferencias en un marco de respeto sobre si tener o no hijas o hijos así como el número e intervalo de los mismos.

La división de esos derechos fue vista, sin embargo, por los grupos conservadores como una puerta para el aborto; así lo señalaba la asambleísta Cristina Reyes: "a través de la introducción de esto, de los conceptos de los derechos sexuales y reproductivos realmente hay aquí una confusión, no entiende como una verdadera planificación familiar sino una velada introducción de prácticas asesinas como es el aborto". ${ }^{48}$

En este contexto, Mario Játiva sacó su biblia y utilizándola como fuente de autoridad normativa leyó sus proverbios para indicar cómo los derechos sexuales y reproductivos constituían la puerta a una degradación moral por la que seríamos castigados por Dios:

'Hay caminos que al hombre le parecen rectos, pero su fin es camino de muerte'. Realmente estamos tocando un tema que es extremadamente delicado [...]de acuerdo como está la propuesta planteada, realmente se está promoviendo de alguna manera el aborto, el libertinaje sexual, la destrucción del núcleo familiar entre hombre y mujer [...] está dirigida hacia la pérdida de valores, desgraciadamente, y hacia una degradación moral. Finalmente expreso que Dios pone autoridades, pero así también las quita y existen dos tipos de gobiernos, para bendición de un país o para maldición y si pasa tal como está esta propuesta, será para lo último: la ira de Dios caerá sobre aquellos que detienen la verdad por la injusticia y esto será hasta la cuarta generación [...] Las naciones han desaparecido de la faz de la tierra naciones enteras, acuérdense de Babilonia, de Sodoma, por la degradación moral... ${ }^{49}$

Los argumentos sobre la sacralidad de la vida, en oposición a los derechos sexuales y reproductivos, fueron abundantes. Los asambleístas conservadores ensalzaban la labor de la mujer pero, en nombre de Dios, advertían que "la capacidad que ustedes tienen de traer al mundo una nueva vida, no les da la facultad de decidir cuándo o de decidir cuántos, porque solamente Dios sabe cuándo y cuántos hijos se podrá tener...". ${ }^{50}$ De este modo, algunos asambleístas hicieron propuestas para limitar el artículo de los derechos sexuales y reproductivos a la moral y a las buenas costumbres, o que o se elimine la frase "cuántos y cuándo", o que se elimine totalmente el artículo. ${ }^{51}$

47. Ibíd., 54-5.

48. Ibíd., 69.

49. Acta del Pleno, Acta No. 050A, 6.

50. Acta del Pleno, Acta No. 064, 98.

51. Archivo de la Asamblea Nacional. Actas del Pleno. Acta No. 037. 27 de mayo de 2008. Las propuestas la hicieron, respectivamente, los asambleístas Rory Delgado, Oswaldo Orrala y Alfredo Ortiz. 
En consecuencia, a pesar de que para satisfacer las pretensiones religiosas Acuerdo País se comprometió a respetar la vida desde la concepción, algunos asambleístas observaban que se irrespetaba el acuerdo por dos motivos: primero, porque los derechos reproductivos tal como estaban planteados permitirían que la mujer pueda abortar; segundo, por no ser especificado claramente el derecho a la vida desde la concepción, por no hacer "caso a Dios". Así lo señalaba Valerio Estacio:

Yo me atrevo a citar [...] el versículo dieciséis "mi embrión, dice, vio Jehová". Es decir que aquí está hablando de que, desde que se produce [...] la penetración de ese embrión, tiene vida. Por lo tanto, dice: "mi embrión vieron tus ojos". [...] Y cuando tocamos, señor Presidente y señores asambleístas, el tema de la vida, es un tema muy complicado, cada uno lo mira desde su punto de vista... Pero he aquí el problema. El hombre, cada día no quiere hacer caso de lo que Dios ha establecido. ${ }^{52}$

El texto que se aprobó finalmente reconoce el derecho a la vida tal como constaba en la Constitución de 1998, así: "El derecho a la inviolabilidad de la vida. No habrá pena de muerte". ${ }^{53} \mathrm{Y}$ en la sección de la niñez y adolescencia se buscó respetar el acuerdo adquirido por Acuerdo País a los creyentes católicos y cristianos y se aprobó el siguiente artículo: "El Estado reconocerá y garantizará la vida, incluido el cuidado y protección desde la concepción". ${ }^{54}$ Los derechos sexuales y reproductivos mantuvieron el contenido originalmente propuesto por la Mesa 1.

\section{InClusión de Dios en la Constitución:}

\section{CLAMOR INELUDIBLE DE UNA SOCIEDAD RELIGIOSA}

Junto con el tema del aborto y el matrimonio homosexual, la inclusión de Dios en el preámbulo de la Constitución ocasionó también un debate en el Pleno de la Asamblea. El argumento de los grupos conservadores se basaba en lo que se ha denominado el "mito de la nación católica". Por su parte, los grupos progresistas rechazaban la inclusión de Dios e insistían, en cambio, en especificar la característica laica del Estado, cuestión que les servía para evitar la prohibición absoluta del aborto y detener los argumentos religiosos que apuntaban a ese fin.

En este apartado se analizarán tres cuestiones: 1. las propuestas tendientes a definir el carácter laico del Estado; 2. el uso de la laicidad para defender los derechos de las

52. Actas del Pleno, Acta No. 064, 81.

53. Constitución del Ecuador. Artículo 66, numeral 1. Promulgada el 20 de octubre de 2008.

54. Ibíd., artículo 45. 
mujeres en contra de dogmas religiosos; y 3. la actuación de las iglesias católicas y evangélicas en la defensa política de sus agendas religiosas.

\section{Carácter laico del Estado y Dios en el Preámbulo}

La discusión acerca de la laicidad como característica del Estado fue labor de la Mesa 3. La mesa aprobó por consenso su inclusión, ${ }^{55}$ de modo que el artículo 1 de la Constitución señala que el Ecuador es un Estado laico. Este fue un tema que no ocasionó mayor discusión al interior del Pleno, pues todos estaban de acuerdo con caracterizar al Estado en ese sentido. Sin embargo, este consenso debía ser discutido en al marco del compromiso adquirido por Acuerdo País de incluir el nombre de Dios en la Constitución.

Así, algunas intervenciones dejaban ver claramente su disposición de incluir el nombre de Dios por su propia fe: "Yo sí creo que el nombre de Dios debe ir en la Constitución porque soy un hombre creyente [...]" ${ }^{56}$ En nombre de la mayoría del pueblo, veían que la inclusión de Dios respondería a esas pretensiones:

Nuestro pueblo ecuatoriano, en su mayoría es creyente y creo que no debemos defraudarlo en este sentido. La Biblia expresa que 'bienaventurada aquella nación cuyo Dios es el creador y la nación que honra a Dios, el creador, será bendecida' [...] vivimos en una nación que estamos expuesta a catástrofes naturales y por la gracia de Dios, todavía, nuestro pueblo ecuatoriano está de pie... ${ }^{57}$

Estas intervenciones tenían como fin indicar que todo aquel que invocara el nombre de Dios estará a salvo. Para Rolando Panchana, el artículo debía ser redactado "respetando las creencias en Dios de amplios sectores de la población", ${ }^{58}$ pues, argumentando el mito de la mayoría católica, indicaba que "esa frase es la que debería estar (en la Constitución) porque eso refleja lo que piensa el $90 \%$ de la población ecuatoriana". ${ }^{59} \mathrm{Al}$ contrario, Tania Hermida consideraba que la mención a Dios, tal como se planteó en los acuerdos de Acuerdo País, deber ser ecuménica, y por tanto mencionar a Dios, pero también "todas las formas de espiritualidad y religiosidad ecuatorianos". ${ }^{60}$

55. La Constitución de 1998 no señalaba nada acerca del carácter laico del Estado.

56. Asambleísta Rafael Esteves. Archivo de la Asamblea Nacional. Asamblea Constituyente. Actas del Pleno. Acta No. 088. 16 de julio de 2008, 5.

57. Ibíd., 9 .

58. "La invocación a Dios trae polémica", El Comercio, 17 de julio de 2008.

59. Ibíd.

60. Acta del Pleno, Acta No. 088, 11. 
Pronto, sin embargo, otros asambleístas que insistían al inicio de la instalación de la Asamblea en que se tomara en cuenta el nombre de Dios, se negaron a incluirlo por dos razones. Primero, porque tomar en cuenta el nombre de Dios había sido producto de un manejo político. Segundo, porque no consideraban "cristiano" incluir a Dios en una Constitución que no estaba apegada a los valores que Cristo enseñó. Señalaba el asambleísta Leonardo Viteri: "Ocho meses ignoraron el nombre de Dios, ocho meses, y ahora a última hora, por conveniencia, [...] ahora sí quieren poner el nombre de Dios", ${ }^{61}$ en otras palabras, se denunciaba la invocación a Dios solo con el fin de que se apruebe la Constitución. ${ }^{62}$

Finalmente, se aprobó el Preámbulo invocando el nombre de Dios, pero también el de la Pacha Mama, y señalando el respeto a todas las formas de espiritualidad. Esto provocó el rechazo de asambleístas religiosos que, como Julio Logroño, rechazaban que además de Dios se invocara a otras "divinidades". ${ }^{63}$

\section{Laicidad y dogmas religiosos}

El Movimiento Nacional de Mujeres, con el respaldo de sesenta asambleístas, buscó posicionar la inclusión y definición del Estado como laico. Incorporar este principio era vital en sus agendas para permitir que el ejercicio de los derechos de las mujeres no se encuentre permeado por concepciones religiosas, como efectivamente sucedió. De esta manera varias asambleístas solicitaron que se dedicara un artículo de la Constitución a la definición del carácter laico del Estado y con ella concluir la revolución iniciada por Eloy Alfaro. ${ }^{64}$

Así, Eloy Alfaro y el laicismo fueron los aliados más importantes para hilar argumentos a fin de defender el aborto terapéutico. Martha Roldós señalaba: "cuando estamos hablando el aborto terapéutico debería ser un asunto de conciencia, una decisión personal y no una imposición del Estado... Estamos en un Estado laico, estamos en un Estado laico en la cuna de Alfaro". ${ }^{65}$ La trascendencia del reconocimiento de

61. Archivo de la Asamblea Nacional. Asamblea Constituyente. Actas del Pleno. Acta No. 095. 24 de julio de 2008, 13.

62. En este sentido también se pronunciaron los asambleístas Andrés Pavón, César Rohón y Julio Logroño. Ibíd., 15-6.

63. Julio Logroño indicaba: "No se puede mezclar en un solo inciso el nombre de Dios con otras formas de religiosidad y espiritualidad", ibíd., 28.

64. Asambleísta María Paula Romo. Archivo de la Asamblea Nacional. Asamblea Constituyente. Actas del Pleno. Acta No. 60. 7 de junio, 42. El Quinche es un santuario y un lugar de peregrinación muy importante en el Ecuador.

65. Acta del Pleno, Acta No. 50, 162. 
este principio se hacía evidente en las discusiones en la Asamblea al observar que el argumento religioso servía para oponerse a los derechos de las mujeres. Tania Hermida advertía, en este sentido, cómo las mujeres siempre han sido un problema para la religión y recreaba su posición de este modo:

El debate de hoy es uno de los más importantes de esta Asamblea, [...] porque estamos ratificándonos como un Estado laico. En este sentido, quisiera recordarle a esta sala, que las mujeres siempre hemos sido un problema para las religiones. Si hoy me he puesto este velo, es para recordar de manera simbólica, que esta costumbre [...] también ha sido y es una costumbre de la religión católica y la tradición judeo-cristina de la que somos herederos, pero a cuyo culto no estamos obligados. Dice la historia del pueblo corinto que al aceptar con buena voluntad la costumbre de usar un velo en la cabeza era un privilegio honorable que indicaba que una mujer ocupaba un lugar de respeto en la comunidad, porque pertenecía a alguien y tenía derecho a pedir sostén protección de aquel bajo cuya autoridad vivía; era una señal de que era casada y también una demostración de pudor. ...Yo me quito el velo, entonces, señor Presidente, para celebrar que estamos escribiendo una Constitución de ciudadanos y ciudadanas libres, que podemos optar entre usar el velo o no usarlos, y donde ser una mujer no supone que optar entre ser la Virgen María o María Magdalena. ${ }^{66}$

Los debates constitucionales en torno al Estado laico entonces adquirían una importancia significativa. Su incorporación no solo suponía que la inclusión del nombre de Dios, o cualquier otra deidad como la Pacha Mama, en la Constitución contradijera la laicidad como principio que separa los mandatos o dogmas religiosas del quehacer del Estado, sino que suponía el desarrollo de leyes y la implementación de políticas públicas en materia de salud y educación sexual sin el paraguas de la moral católica.

El Estado laico y su significado sirvieron, no obstante, solo para contradecir los argumentos conservadores en las discusiones del Pleno. Aunque se caracterizó al Estado como laico, la propuesta para incluir un artículo con su definición no solo no fue aceptado, sino que las pretensiones religiosas finalmente triunfaron: la Constitución protege la vida desde la concepción, prohíbe el matrimonio homosexual e incluye a Dios en su preámbulo. Estos artículos, tal como se observa, auspician y protegen posiciones religiosas.

\section{La iglesia y sus hojas dominicales de catecismo político}

Las iglesias católicas y evangélicas unieron fuerzas para oponerse al proyecto político. Junto con las asambleístas Queirolo, Acosta, Azín y Rosado, entre otras, or-

66. Actas del Pleno, Acta No. 60, 80-1. 
ganizaron múltiples marchas y también misas "campales" a fin de que sus feligreses voten no en el referendo aprobatorio. Para evitar críticas a su intervención política, se justificaban indicando que "No nos corresponde como obispos asumir una actitud política. Nos corresponde, en cambio, iluminar las conciencias de los católicos con la doctrina del Evangelio para que tomen una decisión". ${ }^{67}$

Así, con la idea de iluminar las conciencias de los católicos y evangélicos las iglesias informaban el acontecer político de la Constituyente a través de las hojas dominicales y desde sus púlpitos. ${ }^{68}$ El objetivo fue inducir a los feligreses a votar NO en el proyecto de la Constitución señalando que la prohibición del aborto, del matrimonio homosexual y la inclusión de Dios en la Constitución eran puntos innegociables. Arregui señalaba: "vamos a pedir a toda conciencia cristiana que tome nota de las incompatibilidades no negociables de esta Constitución con nuestra fe". ${ }^{99}$ Para el efecto advertía que la Conferencia Episcopal Ecuatoriana no iniciará una campaña por el no en el referéndum aprobatorio, pero que iniciará "una gran catequesis" para informar a los feligreses el carácter irrenunciable de estos temas. ${ }^{70}$

De este modo, las iglesias se constituyeron en importantes actores políticos, tal como el gobierno lo había previsto y lo había querido evitar. A pocos días del referendo aprobatorio, se celebraron misas en los que los párrocos se refirieron específicamente a estos asuntos "innegociables". En una de sus misas, el párroco Federico Gallardo manifestaba: "Me duele que comparen a mi Dios con la deidad de la tierra (Pacha Mama), creada por los hombres, implantada por los indígenas del Perú... Hoy más que nunca acerquémonos al señor Jesús a tomar de su pan, para que, fortalecidos, no tengamos miedo". ${ }^{71}$ Otras iglesias fueron más lejos: el folleto dominical de 'Nuestra Iglesia', publicó en su portada un "Di no a la Constitución abortista", y se analizaban los artículos del proyecto de Constitución. ${ }^{72}$

La iglesia evangélica apoyó los puntos no negociables de la Conferencia Episcopal Ecuatoriana, y en una unión sin precedentes entre ambas iglesias, siete mil centrales evangélicas respaldaron los pronunciamientos de Arregui, quien afirmó: "Ha sido frecuente la tensión y los roces entre las iglesias evangélicas y católicas. Hoy, con gozo descubro que prima el común patrimonio cristiano para pronunciarnos en defensa de

67. “A. Barrera acusa a la Conferencia Episcopal de tener 'vínculos con la derecha'”, El Comercio, 29 de julio de 2008.

68. "Iglesias informan a sus fieles acontecer político", El Universo, 9 de junio de 2008.

69. "La iglesia pone reparos al proyecto", El Comercio, 29 de julio de 2008.

70. "El anuncio de la Iglesia atiza la polémica", El Comercio, 30 de julio de 2008.

71. Ibíd.

72. Ibíd. 
la familia, de la vida, de la paz y de la unidad del país". ${ }^{73}$ De este modo, los evangélicos, que se consideran un $20 \%$ de la población, se sumaron a la iglesia católica en su oposición al proyecto constitucional. ${ }^{74}$

Las iglesias se constituyeron como sujetos políticos que, aprovechando los púlpitos, insistieron en la defensa de la vida, de la familia y el respeto a Dios. Lo hicieron con argumentos parecidos a los utilizados por los asambleístas en la Constituyente: con razonamientos religiosos. Aquello confirmaba la necesidad que mostraban los asambleístas progresistas de definir qué es un Estado laico, cuestión que tampoco fue aprobada.

\section{MATRIMONIO Y UNIÓN LIBRE: INSTITUCIÓN EXCLUSIVA}

\section{DE PAREJAS DE DISTINTO SEXO}

Los debates sobre el matrimonio y/o la unión libre de parejas del mismo sexo también fueron temas polémicos al que los grupos conservadores se oponían a través de razonamientos falaces naturalistas; es decir, argumentos descriptivos que se convierten en argumentos prescriptivos. A partir de esta falacia, se dice que, dado que únicamente los hombres y las mujeres pueden procrear cuando interactúan sexualmente, entonces es bueno que las parejas sean únicamente heterosexuales. En otras palabras, hay una derivación del ser a lo que debe ser, que no se sigue: la valoración de la procreación como bueno conduce a una visión de "antinatural" a las relaciones sexuales que no pueden procrear, o sea una valoración mala. Este juicio de valor corresponde, pues, a concepciones religiosas.

La discusión sobre este tema inició desde el debate acerca de los derechos sexuales que, tal como se señaló, reconocía el derecho a tomar decisiones sobre la orientación sexual. Así, Andrés Pavón señalaba que los derechos sexuales son una 'atrocidad' pues estos solo se pueden comprender en las relaciones de hombres con mujeres: "no podemos dar facultad a otro tipo de vinculación de hombre con hombre o mujer con mujer. [...] yo estoy en contra de que se quiera dar ese tipo de aperturas en esta nueva Carta Política, porque eso es completamente contra la naturaleza humana. La naturaleza humana es la unión de un hombre con una mujer y nada más". ${ }^{75}$ Entendida entonces como una circunstancia antinatural, Valerio Estacio recreaba esta opción como una pelea entre el bien y el mal y la posibilidad de curar a los homosexuales y regresarlos a su estado normal:

73. "La Iglesia suma apoyo", El Comercio, 23 de agosto de 2008.

74. "Evangélicos rechazan proyecto de Constitución por abortista", El Comercio, 10 de septiembre de 2008.

75. Actas del Acta, Acta No. 064, 98. 
También aquí hablamos de reconocer derechos a los que han cambiado su estado natural, amamos a los homosexuales [...] la Iglesia Cristiana ha ofrecido cinco mil centros de cambio y de transformación al homosexual... hay cosas que el hombre natural no entiende, son fuerzas demoníacas que al hombre lo hacen cambiar su sentido normal. ${ }^{76}$

El tratamiento del matrimonio y la unión libre se dio en los debates relativos a la familia. El primer informe de mayoría hacía alusión a la unión libre entre parejas, sin aludir a su sexo. En cambio, el informe de minoría reconocía la unión libre solo entre un hombre y una mujer y agregaba el siguiente artículo: "Las parejas del mismo sexo podrán exigir derechos patrimoniales y sucesorios, previa declaración juramentada sobre el lazo de unión". ${ }^{77}$

La posibilidad de que las parejas homosexuales puedan constituirse en familia también era un temor grande entre los conservadores, quienes veían estas circunstancias como una forma de libertinaje y un peligro para la sociedad. Así lo decía Pablo Lucio Paredes: "Hay que proteger, creo y estoy convencido, a los menores en el caso de adopciones de parejas homosexuales...". ${ }^{78}$ En todo caso, se reconoció la unión libre de cualquier pareja, pero se prohibió expresamente la adopción por parte de parejas del mismo sexo.

Posteriormente, la Mesa 1 incluyó en el articulado el concepto de matrimonio señalando que: "El matrimonio se fundará en el libre consentimiento de los contrayentes y en la igualdad de derechos, obligaciones y capacidad legal de los cónyuges". ${ }^{79}$ Como se advierte, hasta aquí las parejas homoafectivas podrían haber optado por el matrimonio. Esto causó intervenciones que rechazaban tal posibilidad a través de argumentos religiosos que apuntaban otra vez a precautelar el matrimonio y la familia como institución natural, divina. Queirolo enfatizaba:

La familia es una institución natural y con eso no se juega, los que no crean en Dios, los que no crean en la familia son un grupo minúsculo, mayúsculo en esta Asamblea pero no en el país, con esta institución sagrada no se debe jugar [...] existe un solo tipo de familia formada por la unión de un hombre y una mujer [...] La familia es la célula básica de la sociedad desde siempre, esta idea ha pasado a ser un lugar común, no discutido en ninguna cultura, tiempo o lugar, y siempre ha estado constituida por la unión entre un hombre y una

76. Actas del Pleno, Acta No. 050, 154-5.

77. Actas del Pleno, Acta No. 077, 145

78. Actas del Pleno, Acta No. 050, 128.

79. Archivo de la Asamblea Nacional. Asamblea Constituyente. Mesa 1. Acta No. 47-08. Caja 2. Folder 17. Dispositivo 10. 11 de julio de 2008. 
mujer cuyo principal objetivo es la procreación para la permanencia de la sociedad, si el objetivo no es procrear, no son familia... ${ }^{80}$

En la votación definitiva, en medio del caos y el desorden por la votación final de todos los artículos, se propuso una reconsideración sobre el artículo del matrimonio a fin de apoyar a la familia del Ecuador entre un hombre y una mujer, ${ }^{81} \mathrm{y}$ se propuso la inclusión del matrimonio como la unión entre hombre y mujer. La reconsideración fue aceptada y la mayoría de asambleístas votó positivamente. Este es el texto que se aprobó en el referendo:

El matrimonio es la unión monogámica entre hombre y mujer [...] La unión estable y monogámica entre dos parejas libre de vínculo matrimonial [...] generará los mismos derechos y obligaciones que tienen las familias constituidas mediante matrimonio. La adopción corresponderá solo a parejas de distinto sexo. ${ }^{82}$

\section{LA FE PRESIDENCIAL}

En relación con estos temas, el presidente intervino en la Constituyente en dos momentos. Primero indicando que, en el caso de que la Constitución permitiera el aborto, él personalmente votaría que no ${ }^{83}$ En esta medida apoyó a Queirolo y Acosta a quienes indicó que como creyente estaría de acuerdo con sus criterios ${ }^{84}$ En un segundo momento, y a fin de serenar las aguas en Acuerdo País, el presidente reunió a todos sus asambleístas quienes, presididos por la fe presidencial, redactaron el Comunicado señalado supra en la que Acuerdo País garantizaba que la Constitución respetaría la vida desde la concepción, prohibiría el matrimonio homosexual y se incluiría el nombre de Dios en la Constitución.

De este comunicado se derivaron consecuencias (in)esperadas. En el mes de octubre de 2013, el presidente hizo manifiesta su oposición a la despenalización del aborto y al matrimonio homosexual. Ocurrió durante la discusión que se mantenía en la Asamblea Nacional durante la elaboración de un nuevo Código Penal. La asambleísta Paola Pabón, de Alianza País, propuso un proyecto de ley en el que se despenalizaba

80. Archivo de la Asamblea Nacional. Asamblea Constituyente. Actas del Pleno. Acta No. 086. 15 de julio de 2008, 97.

81. Archivo de la Asamblea Nacional. Asamblea Constituyente. Actas del Pleno. Acta No. 089, 17 de julio de 2008, 44.

82. Constitución del Ecuador, artículos 67 y 68.

83. "Dios, aborto y matrimonio homosexual no deben ir en la Constitución, según Cordero", El Comercio.

84. "El Presidente respalda a Queirolo y a Diana Acosta", El Comercio, 1 de abril de 2008. 
el aborto en el caso de violación..$^{85} \mathrm{~A}$ la vez solicitó que esta propuesta fuera votada de manera individual y no como bancada. La moción fue apoyada por Soledad Buendía y Gina Godoy (exconstituyente).

El proyecto causó la irritación del presidente Correa, quien, en una entrevista al canal de televisión Oromar, amenazó con renunciar a su cargo si se mantenía la moción de que se despenalice el aborto. Considerando que el presidente tiene poder de veto, agregó: "yo jamás aprobaré la despenalización del aborto más allá de lo que consta en las actuales leyes". ${ }^{86}$ A partir de estas declaraciones, Paola Pabón retiró su proyecto para que no hubiera una ruptura al interior del bloque. Días después, el presidente pidió que se sancione a las asambleístas por haber violado el Código de Ética al haber mocionado que cada asambleísta vote individualmente y por haber violado los acuerdos relativos a la no despenalización del aborto; acuerdos que se deducen de los compromisos adquiridos por Alianza País en la Constituyente. Se sancionó a Paola Pabón, Gina Godoy y Soledad Buendía con un mes de inhabilitación por la ruptura de acuerdos. ${ }^{87}$

En relación al matrimonio homosexual, el presidente tuvo otra vez la ocasión de manifestar su desacuerdo con este tema al proponer un proyecto de ley que planteaba cambiar en la cédula de identidad la categoría "sexo" por "género". A partir de este cambio se observó la posibilidad de que parejas con identidad de género distinta a la de su sexo puedan contraer matrimonio. Correa se negó a esta posibilidad y, en una entrevista concedida a RTS sobre este tema, el entrevistador le dijo al Presidente: "yo creía que usted era más liberal" ${ }^{88}$ a lo que Correa respondió:

Yo soy muy progresista en la parte económico y social, pero bastante conservador en cuestiones morales y no es que pretendo mis principios, mis valores personales transmitirlos al país aunque tengo todo el derecho y porque nunca los he ocultado y el país ha votado por mí, por la persona, por sus creencias, etc., [...] yo sí creo que la familia es el fundamento de la sociedad y como la estrategia era cambiar sexo por identidad de género y luego como mi identidad de género es ser mujer entonces "hombre mujer" no rompo la Constitución y hay matrimonio gay y yo lo he dicho claramente no estoy de acuerdo con esa postura. ${ }^{89}$

85. De acuerdo al artículo 150 del Código Penal Integral, el Ecuador permite el aborto terapéutico en caso de peligro a la salud de la madre, siempre que no hayan otros medios disponibles, y en el caso de la violación a una mujer con discapacidad mental.

86. Ibíd.

87. "Rafael Correa dice que Alianza País sancionó la indisciplina y no pensar distinto", El Comercio, 29 de octubre de 2013.

88. RTS. Entrevista a Rafael Correa. Disponible en 〈http://www.youtube.com/watch?v=1YJG8LSmVGo〉.

89. Ibíd. 
La posición del presidente ha merecido un titular muy decidor en la prensa internacional: "La izquierda beata de América Latina" ${ }^{90}$ para denominar la ideología de presidentes identificados con la izquierda, pero que, a la hora de tratar temas como el aborto o el establecimiento del matrimonio gay, "sus posiciones tienden al conservatismo, y el mensaje religioso es incorporado cada vez con mayor frecuencia en sus discursos político y en su argumentación". ${ }^{91}$ La definición es coherente con la etiqueta que se ha dado el propio presidente como un 'humanista, católico y de izquierda'. Su posición se encuentra reflejada en los artículos de la Constitución tratados en este trabajo y que revelan su fundamentación y origen en dogmas religiosos.

\section{CONCLUSIONES}

La Constitución del Ecuador, aprobada en 2008, caracteriza al Estado como laico. Sin embargo, esa caracterización es tan solo formal pues el reconocimiento constitucional a la protección a la vida desde la concepción, la prohibición del matrimonio homosexual y la inclusión de Dios en su preámbulo están marcados por una cruz: su inclusión en texto constitucional responde a dogmas religiosos. Para probar esta hipótesis, la presente investigación analizó tres razones que dan cuenta de la enorme influencia que la religión tiene todavía en el Ecuador, motivo que impediría pensar que el Estado es efectivamente laico, y que, por tanto, no promociona ni favorece ninguna tendencia religiosa.

En la primera parte del trabajo se explicitó el fundamento de la instalación de la Asamblea Constituyente de 2008: iniciar un proceso revolucionario que siguiera las huellas de Eloy Alfaro, líder de la Revolución liberal ecuatoriana acaecida en 1897. La consecuencia natural de seguir el pensamiento de Alfaro debió haber sido concluir con el proceso laicización del Estado que él inició por primera vez en la historia del Ecuador. No obstante, las tres razones que se desarrollan en este trabajo pretendieron demostrar que el intento por constituir un Estado laico fue fallido. Con el fin de estudiar las razones que sustentan esta hipótesis, el trabajo se sirvió de los debates constituyentes acaecidos en el Pleno de la Asamblea Constituyente, así como en las mesas encargadas de desarrollar los artículos correspondientes. También se utilizaron noticias de la prensa que recogían las intervenciones de los asambleístas, pero también de actores importantes en este debate: el presidente de la República, las iglesias católicas y evangélicas y el Movimiento Nacional de Mujeres.

90. "La izquierda beata de América Latina", El País, 26 de octubre de 2013.

91. Ibíd. 
El manejo político que se dio a estos temas reveló que en el Ecuador todavía se deben satisfacer pretensiones religiosas para lograr legitimidad política y asegurar resultados electorales. Tal como se demostró, para Acuerdo País, el partido político de gobierno, era importante asegurar los votos de los creyentes, razón por la que concretaron un acuerdo que buscaba que estos votaran positivamente en el referendo aprobatorio de la Constitución. Así, se privilegiaron las visiones eclesiales en detrimento de un Estado neutro religiosamente que permita el ejercicio de los derechos sin el prisma de la moralidad católica.

El análisis de los debates constituyentes también demostró que los argumentos que sostenían las facciones conservadoras para prohibir el aborto, el matrimonio homosexual e incluir la a Dios en el preámbulo fueron esencialmente razonamientos religiosos que desconocían la pretensión laica del Estado. Los argumentos religiosos que frecuentemente se utilizaron fueron de tres tipos: 1. El mito de la mayoría católica, en virtud del cual el llamado religioso del pueblo cristiano era ineludible; 2. La Biblia como fuente de Derecho, a partir del cual los artículos constitucionales debían respetar la voluntad divina; 3. El argumento falaz naturalista que vuelve inmorales ciertas conductas que no se corresponden con la realidad tal como es. Fueron estos argumentos los que finalmente se impusieron a la hora de solucionar los conflictos que se produjeron alrededor de estos temas entre los grupos conservadores y los grupos progresistas de la Asamblea Constituyente.

Por último, la tercera razón que se expone para dudar del Estado laico en el Ecuador es la misma posición del presidente del Ecuador que, reconociéndose como un humanista de izquierda católico, ha manifestado públicamente que durante su gobierno no se despenalizará el aborto y tampoco se dará paso al matrimonio homosexual. El motivo de esta oposición, tal como ha manifestado, es su fe católica, fe que se impone al pretendido carácter laico del Estado.

\section{BIBLIOGRAFÍA}

Bloch, Marc. "La crítica". En Apología para la historia o el oficio de historiador. México: Fondo de Cultura Económica, 2001.

Carr, Edward H. ¿Qué es la historia? Barcelona: Ariel, 1984.

Carta de Eloy Alfaro dirigida a Ángel T. Barrera, su secretario privado. En Historia del ferrocarril de Guayaquil a Quito. Páginas de verdad escritas por el General Eloy Alfaro, gestor de la magna obra. Quito: Ministerio de Cultura, 2008.

Castello Starkoff, Paula. "Despenalización del aborto y nuevo proyecto constitucional: un tema polémico". Íconos: Revista de Ciencias Sociales. Quito (2008).

Dworkin, Ronald. Moral Freedom's Law: The Moral Reading of the American Constitution. Cambridge: Harvard University Press, 1996. 
---. Religion without God. Cambridge/London: Harvard University Press, 2013.

Haberle, Peter. Teoría de la Constitución como ciencia de la cultura. Madrid: Tecnos, 2000.

Habermas, Jürgen. "Del uso pragmático, ético y moral de la razón práctica". En Aclaraciones a la ética del discurso. Madrid: Trotta, 2000.

---. “QQué significa una sociedad postsecular?”. En ;Ay Europa! Madrid: Trota, 2009.

---. Una tarde de discusión entre Habermas y Ratzinger. s. 1.: Academia Católica de Baviera, 2004.

Herrera, Elizabeth, y Paulina Ponce. Mujeres a media tinta ¿Cómo trató la prensa escrita ecuatoriana los derechos de las mujeres durante la Asamblea Constituyente? Quito: CONAMU, 2008.

Hidalgo, Ángel Emilio. "Una interpretación de la Hoguera Bárbara: Quito, 28 de enero de 1912”. Procesos: Revista ecuatoriana de historia. Quito (2012).

Lalander, Rickard, y Pablo Ospina Peralta. "Movimiento indígena y revolución ciudadana en Ecuador”. Cuestiones Políticas, vol. 28, No. 48 (2012).

Muñoz, Juan Pablo. "Movimientos sociales y procesos constituyentes. El caso de Ecuador 2008". s. 1.: Instituto de investigación y debate sobre la gobernanza, 2008. Disponible en 〈http://www.institut-gouvernance.org/es/analyse/fiche-analyse-451.html〉.

Posner, Richard. Against Constitutional Theory. New York: University Law Review, 1998.

Prost, Antoine. "Las técnicas de la crítica". En Doce lecciones sobre la historia. Madrid: Cátedra, 2001.

\section{Otros}

\section{Archivo de la Asamblea Nacional. Asamblea Constituyente. Actas del Pleno de la Asamblea}

Acta No. 009. 12 de diciembre de 2007.

Acta No. 050. 12 de mayo de 2008.

Acta No. 050 A. 16 de mayo de 2008.

Acta No. 079. 8 de julio de 2008.

Actas del Pleno. Acta No. 037. 27 de mayo de 2008.

Actas del Pleno. Acta No. 060. 7 de junio de 2008.

Actas del Pleno. Acta No. 064. 18 de junio de 2008.

Actas del Pleno. Acta No. 077. 5 de julio de 2008.

Actas del Pleno. Acta No. 086. 15 de julio de 2008.

Actas del Pleno. Acta No. 088. 16 de julio de 2008.

Actas del Pleno. Acta No. 089. 17 de julio de 2008.

Actas del Pleno. Acta No. 095. 24 de julio de 2008. 


\section{Actas y documentos de las mesas constituyentes}

Asamblea Constituyente. Propuesta de la Conferencia Episcopal Ecuatoriana. Mesa 3. Caja 5. Folder 58. Dispositivo 5. 14 de abril de 2008.

Asamblea Constituyente. Propuesta del Mandato de Pueblos Indígenas y Evangélica de Kichwas de la Costa. Mesa 3. Caja 5. Folder 19. Dispositivo 6. 9 de mayo de 2008.

Asamblea Constituyente. Carta de Ministra Caroline Chang a Presidente Correa. Mesa 3. Caja 3. Folder 19. Dispositivo 6. 29 de mayo de 2008.

Asamblea Constituyente. Mesa 1. Acta No. 45-08. Caja 2. Folder 17. Dispositivo 9. 27 de junio.

Asamblea Constituyente. Mesa 1. Acta No. 037. Caja 2. Folder 3. Dispositivo 7. 27 de mayo de 2008.

Asamblea Constituyente. Mesa 1. Acta No. 44-08. Caja 2. Folder 17. Dispositivo 8. 20 de junio de 2008.

\section{Prensa}

\section{Diario El Comercio}

“A. Barrera acusa a la Conferencia Episcopal de tener "vínculos con la derecha"”. 29 de julio de 2008.

“Asamblea aprueba cinco primeros artículos de la nueva Constitución”. 1 de abril de 2008.

"Dios, aborto y matrimonio homosexual no deben ir en la Constitución, según Cordero". 26 de marzo de 2008.

"El aborto, el nombre de Dios... dividen al bloque de A. País". 28 de marzo de 2008.

"El anuncio de la Iglesia atiza la polémica". 30 de julio de 2008.

“El preámbulo del proyecto para nueva Constitución sí invoca a Dios”. 24 de julio de 2008.

“El Presidente respalda a Queirolo y a Diana Acosta". 1 de abril de 2008.

"Evangélicos rechazan proyecto de Constitución por abortista". 10 de septiembre de 2008.

"El tema del aborto preocupa políticamente al Gobierno". 5 de julio de 2008.

Gonzalo Maldonado Albán. "Conservador y retardatario". 6 de abril de 2004.

"La Asamblea Constituyente sí debatirá temas polémicos". 27 de abril de 2008.

"La iglesia pone reparos al proyecto". 29 de julio de 2008.

"La Iglesia se divide frente al "no"”. 4 de abril de 2008.

"La Iglesia suma apoyo". 23 de agosto de 2008.

“La invocación a Dios trae polémica”. 17 de julio de 2008.

"Las organizaciones de mujeres rechazaron posición de A. País". 2 de abril de 2004.

"Las organizaciones de mujeres rechazaron posición de A. País". 2 de abril de 2008. 
"Paola Pabón retira el proyecto sobre aborto tras amenaza de renuncia de Rafael Correa". 11 de octubre de 2013.

"Propuesta: los cristianos en contra del aborto". 26 de marzo de 2008.

"Rafael Correa dice que Alianza País sancionó la indisciplina y no pensar distinto". 29 de octubre de 2013.

Redacción Política. "La Asamblea Constituyente sí debatirá temas polémicos”. 27 de marzo de 2008.

“1000000 firmas contra el aborto". 25 de marzo de 2008.

\section{Diario El Universo}

"Iglesias informan a sus fieles acontecer político". 9 de junio de 2008.

"Mujeres denuncian injerencia de asesor de Correa en Asamblea". 5 de julio de 2008.

\section{Diario El País}

“La izquierda beata de América Latina”. 26 de octubre de 2013.

\section{Presidencia de la República}

Discurso del Presidente Rafael Correa en la recepción de los restos del General Eloy Alfaro a Montecristi. Montecristi. 30 de noviembre de 2007.

Intervención del Presidente de la República, Rafael Correa en la ceremonia de clausura de la Asamblea Nacional Constituyente. Montecristi. 25 de julio de 2008.

\section{Oromar}

Entrevista a Presidente Rafael Correa. Disponible en $\langle$ http://www.youtube.com/watch?v=Wm rrP1PBwGc>.

\section{RTS}

Entrevista a Rafael Correa. Disponible en 〈http://www.youtube.com/watch?v=1YJG8LSm VGo〉. 